This is the final peer-reviewed accepted manuscript of

SCARPONI, DANIELE; AZZARONE, MICHELE; Kusnerik, Kristopher; Amorosi, Alessandro; Bohacs, Kevin M.;

Drexler, Tina M.; Kowalewski, Michaå: Systematic vertical and lateral changes in quality and time resolution of the macrofossil record: Insights from Holocene transgressive deposits, Po coastal plain, Italy. MARINE AND PETROLEUM GEOLOGY 87. ISSN 0264-8172

DOI: 10.1016/j.marpetgeo.2017.03.031

The final published version is available online at:

http://dx.doi.org/10.1016/i.marpetgeo.2017.03.031

Rights / License: The terms and conditions for the reuse of this version of the manuscript are specified in the publishing policy. For all terms of use and more information see the publisher's website. 


\title{
Systematic vertical and lateral changes in quality and time resolution of the macrofossil record: Insights from Holocene transgressive deposits, Po coastal plain, Italy
}

\author{
Daniele Scarponi ${ }^{\mathrm{a},{ }^{*}}$, Michele Azzarone ${ }^{\mathrm{a}}$, Kristopher Kusnerik ${ }^{\mathrm{b}}$, Alessandro Amorosi ${ }^{\mathrm{a}}$, \\ Kevin M. Bohacs ${ }^{c}$, Tina M. Drexler ${ }^{c}$, Michał Kowalewski ${ }^{\mathrm{b}}$ \\ ${ }^{a}$ Dipartmento di Scienze Biologiche, Geologiche e Ambientali, University of Bologna, Via Zamboni 67, 40126 Bologna, Italy \\ ${ }^{\mathrm{b}}$ Florida Museum of Natural History, University of Florida, 1659 Museum Road, Gainesville, FL 32611, USA \\ ${ }^{\mathrm{c}}$ ExxonMobil Upstream Research Company, 22777 Springwoods Village Parkway, Spring, TX 77389, USA
}

\section{A R T I C L E I N F O}

Keywords:

Taphonomy

Benthic invertebrates

Stratigraphic paleobiology

Holocene

Po plain

Sequence stratigraphy

\begin{abstract}
A B S T R A C T
In siliciclastic marine settings, skeletal concentrations are a characteristic feature of transgressive intervals that provide insights into biological and sequence stratigraphic processes. To investigate taphonomic signatures of transgressive intervals, we analysed three cores along a depositional profile from the high resolution chrono and stratigraphic framework of the Holocene Po coastal plain, in northern Italy. Coupled multivariate taphonomic and bathymetric trends delineated spatial and temporal gradi ents insediment starvation/bypassing, suggesting that quality and resolution of the fossil record vary predictably along the studied depositional profile. Moreover, integration of taphonomic, bathymetric, and fossil density trends across the study area reveals distinctive signatures useful in characterizing facies associations and determining surfaces and intervals of sequence stratigraphic significance. Within the southern Po plain succession, taphonomic degradation of macroskeletal remains increases from proximal/ nearshore to distal/offshore locations. This trend is discernible for both biologically driven (bioerosion) and physically driven (e.g., dissolution, abrasion) shell alterations. Compared to the up dip (most proximal) core, the down dip core is distinguished by shell rich lithosomes affected by ecological condensation (co occurrence of environmentally non overlapping taxa) and by higher taphonomic alteration. The onshore offshore taphonomic trend likely reflects variation in sediment accumulation along the depositional profile of the Holocene Northern Adriatic shelf, with surface/near surface residence time of macroskeletal remains increasing down dip due to lower accumulation rates. These results indicate that, during transgressive phases, changes in sea level (base level) are likely to produce down dip taphonomic gradients across shelves, where the quality and resolution of the fossil record both deteriorate distally. Radiocarbon calibrated amino acid racemisation dates on individual bivalve specimens and the chronostratigraphic framework for this profile suggest jointly that the high levels of taphonomic degradation observed distally developed over millennial time scales ( $\sim 8 \mathrm{ky})$. Whereas in proximal setting overall low taphonomic degradation and geochronologic constrains point to centennial scale time averaging during the late transgression phase. Patterns documented in the Ho locene transgressive (and lowermost regressive) deposits of the southern Po Plain may be characteristic of siliciclastic dominated depositional systems that experience high frequency, base level fluctuations.
\end{abstract}

\section{Introduction}

In marine settings, skeletal concentrations often represent the geologic by product of a complex interplay between the rate of

\footnotetext{
* Corresponding author.

E-mail address: daniele.scarponi@unibo.it (D. Scarponi).
}

production of skeletal material (biogenic) and variations in clastic sediment supply/accumulation (Kidwell, 1986; Tomasových et al., 2006). In siliciclastic dominated depositional settings, the close association of skeletal rich deposits with prominent sequence stratigraphic surfaces (e.g., Holland, 2000; Patzkowsky and Holland, 2012; Amorosi et al., 2014; Scarponi et al., 2014; Aucoin et al., 2016; Danise and Holland, 2017) suggests that taphonomically complex, fossil rich lithosomes are primarily a 
product of the interaction between sedimentation and accommodation. Consequently, variations in the taphonomic signature of siliciclastic fossiliferous deposits may be driven primarily by sedimentary inputs and depositional processes (i.e., R sediment model of Kidwell, 1985, 1986), or by variations in the production rate of biogenic skeletal remains (i.e., the $\mathrm{R}$ hardpart model; see Tomašových et al., 2006). This assumption has been successfully corroborated by qualitative and quantitative studies of several Quaternary (and older) siliciclastic successions around the globe (Kidwell, 1989; Meldahl, 1990; Abbott et al., 2005; Cantalamessa et al., 2005; Tomašových et al., 2006; Scarponi and Kowalewski,

2007; Zecchin and Caffau, 2011; Ávila et al., 2015; Scarponi et al., 2016; Brady, 2016).

Given these considerations, taphonomic characterization of marine fossil assemblages could aid environmental interpretation and may offer a potentially useful tool for identifying and delineating sequence stratigraphic units and their bounding surfaces (e.g., Brett, 1998; Holland, 2000; Dominici, 2001; Huntley and Scarponi, 2012; Zecchin and Catuneanu, 2013; Horodyski et al., 2014; Giannetti and Monaco, 2015). This is especially true when stratigraphic interpretations are based on cores, for which information on the geometry of sedimentary bodies is exceedingly limited. In such cases the study of taphonomic and paleoecologic attributes of skeletal concentrations can provide an additional strategy for assessing the formational histories and stratigraphic development of cored successions. Here, we focus on the quantitative taphonomy of mainly transgressive fossiliferous lithosomes (with particular emphasis on marine deposits) from cores in the Holocene Po Plain succession (northern Italy) within the context of previously established, high resolution facies, chronostratigraphic, and sequence stratigraphic frameworks (Fig. 1; see Amorosi et al., 2017). Specifically, this study aims to: (1) compare taphonomic attributes of skeletal concentrations within and across genetically related segments of the $\sim 30 \mathrm{~km}$ long nearshore to shallow marine dispersal system developed during the Holocene transgression; and (2) employ ecologic and taphonomic features of fossil assemblages to identify prominent sequence stratigraphic surfaces (e.g., maximum flooding surface MFS) and intervals (e.g., condensed section (S), as well as investigate systematic changes along the studied profile.

\section{Sequence-stratigraphic framework of the latest Quaternary Po plain succession}

The latest Quaternary deposits ( $<30 \mathrm{ky}$ ) of the southern Po Plain represent a few tens of meters thick succession of siliciclastic sediments. Extensive subsurface investigations conducted during the past few decades have led to a detailed reconstruction of the region's stratigraphic architecture (e.g., Amorosi et al., 1999; Scarponi and Kowalewski, 2004; Correggiari et al., 2005; Stefani and Vincenzi, 2005; Storms et al., 2008; Amorosi et al., 2016; Bruno et al., 2016; Calabrese et al., 2016; Scarelli et al., 2017). The lowermost part of this succession consists of alluvial facies deposited during the Last Glacial Maximum (30 18ky BP) and initial eustatic rise (18 14ky BP) phases, when sea level was approximately 120 to $90 \mathrm{~m}$ lower than today. Its upper portion (mainly Holocene in age), is dominated by a variety of transitional to shallow marine deposits, accumulated during rapid eustatic rise (14 7ky BP) and subsequent highstand (6ky BP onward). In the study area, these genetically related strata, up to $40 \mathrm{~m}$ in thickness, represent the Last Glacial Maximum (LGM) depositional sequence (Amorosi et al., 2017) which is dominated by aggradational alluvial and upper coastal plain facies associations (Lowstand sys- tems tract-LST). The LST transitions upwards into retrogradational muddy lower coastal plain to shallow marine deposits
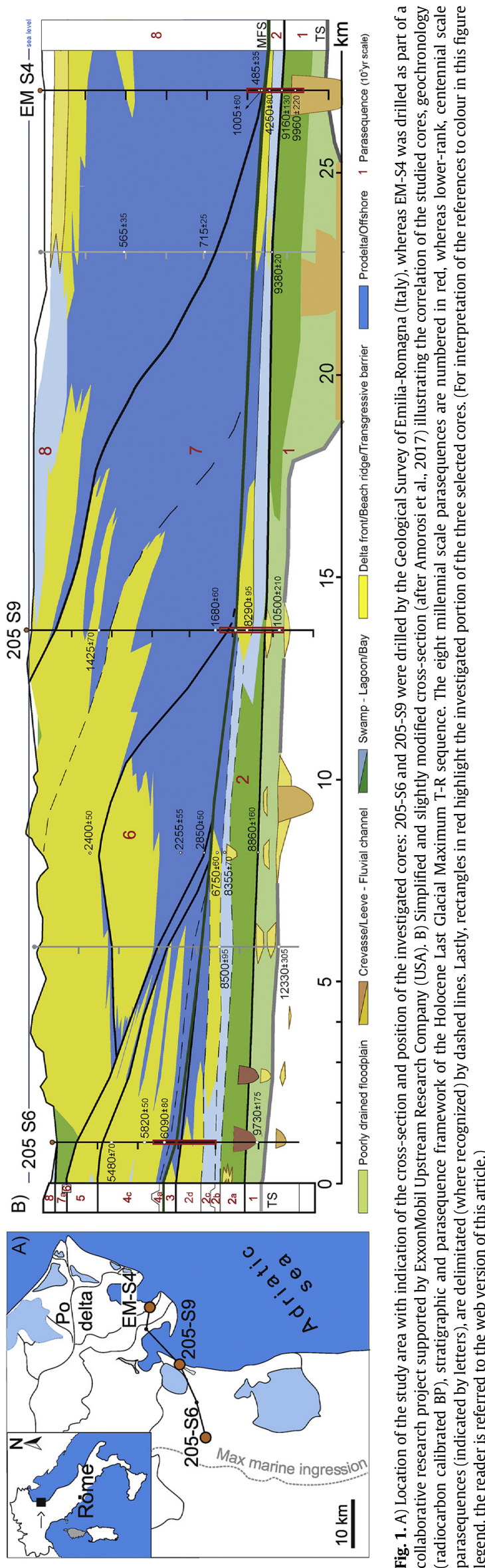
(Transgressive systems tract-TST) overlain by a mosaic of deltaic to coastal plain deposits reflecting the subsequent Holocene pro gradation (Highstand systems tract-HST). Eight higher order depositional successions (meter thick parasequences) that developed over centennial to millennial time scales characterize the internal structure of the LGM sequence (Fig. 1B). These parasequences, geochronologically well constrained (Fig. 1B), can be defined by their characteristic bounding surfaces, internal stacking patterns, and geometric relations to surrounding strata (see Amorosi et al., 2017).

\section{Methods}

Three cores along a $\sim 30 \mathrm{~km}$ down dip transect across the southern Holocene Po Plain were investigated in this study (Fig. 1). Detailed (20 cm scale) stratigraphic description of the investigated portion of each core provides the depositional context for the fossiliferous deposits. Core 205 S6 is proximal to the shoreline at the time of maximum marine ingression $(<5 \mathrm{~km}$ from shoreline), core 205 S9 is intermediate $(\sim 18 \mathrm{~km})$, and core EM S4 is distal ( $\sim 30 \mathrm{~km}$; Fig. 1). The brackish to marine (TST) and lowermost marine (HST) core sections were sampled at high resolution $(\sim 5 \mathrm{~cm}$ intervals, $\sim 250 \mathrm{~cm}^{3}$ of sediment, commonly every $25 \mathrm{~cm}$ or more closely spaced in richly fossiliferous intervals) to quantitatively evaluate faunal composition, ecologic characteristics, and taphonomic attributes of macroskeletal assemblages (raw data are provided in supplementary material). In total, 50 samples were dried for $24 \mathrm{~h}$ at $40{ }^{\circ} \mathrm{C}$, then soaked in $\sim 4 \% \mathrm{H}_{2} \mathrm{O}_{2}$ ( $\leq 12 \mathrm{~h}$, depending on lithology) and wet sieved (see also Scarponi and Angeletti, 2008). The laboratory treatment is unlikely to have induced any notable alterations of the sampled shell material because we used a highly diluted peroxide for a short interval of time. Sample level bathy metric estimates were derived by employing non metric multidimensional scaling (nMDS) of species abundance data. These water depth estimates were integrated with high resolution facies analyses (Fig. 1). Lowermost HST deposits were investigated to constrain, at dm scale resolution, the turnaround between trans gressive and regressive stacking patterns.

nMDS is a dimension reducing multivariate technique that or dinates samples in a reduced space of 2 or 3 dimensions using arbitrarily scaled scores. This approach was also used to recognize and characterize backstepping nearshore (here the main focus) from aggrading shallow marine deposits (TST vs. lowermost HST). The nMDS ordination was conducted on a matrix of relative species abundance using Bray-Curtis distance. The acceptable value of stress $(<0.20)$ resulted from nMDS performed in two dimensions ( $2 \mathrm{k}$ ). Bathymetric estimates were obtained by regressing nMDS 1 sample scores against sample level bathymetric data obtained by specimen weighted averaging of a subset of species with known bathymetric distribution. This method is fully explained in Wittmer et al. (2014); see EG DC: posterior calibration of ordination scores using preferred depth of taxa; see also Tables S1 and S2 in supplementary material).

In order to investigate taphonomic degradation patterns within cores and across the depositional gradient, percent volume of skeletal remains retrieved in each sample was recorded and 60 shells, or fragments larger than $2 \mathrm{~mm}$, were randomly selected from each sample and inspected for taphonomic damage. Samples with scarce fossils content ( $\mathrm{n}<60$ fragments/shells) were not examined. A total of 45 samples yielded sufficient material for taphonomic investigations. Each specimen was examined with a binocular microscope using $10 \times$ magnification, and six variables were recorded and scored following the protocol defined in Table 1. Fragments/shells varied in dimension from 2 to $40 \mathrm{~mm}$. As shell/ fragment size could potentially introduce an area related bias (i.e., larger fragments offer more surface for examination), the analyses were computed focusing only on the more abundant size classes (2-6 mm). Sample size $[n]$ remained reasonably adequate after the culling of specimens larger than $6 \mathrm{~mm}$ ( $n$ range: $35-59$, mean $n$ : 51; 2290 fragments/specimens total). The multivariate taphonomic relations between all samples were also explored using nMDS. The pairwise distances between samples were based on multivariate Euclidean distances using $\mathrm{z}$ scored \% values of taphonomic vari ables. That is, for each sample, a relative abundance score for each taphonomic state was computed separately for each taphonomic variable. For each taphonomic state, relative abundances were $\mathrm{z}$ standardized (scaling to zero mean and unit variance) to ensure comparable weighting of all variables. The nMDS ordination was employed to visualize relative similarities of all samples in terms of their taphonomic signatures. The nMDS performed in $2 \mathrm{k}$ returned a good value of stress (0.123). For each core, nMDS derived taphonomic profiles were plotted along stratigraphic architecture to help delineate taphonomic trends and contrasted with nMDS derived bathymetric profiles. Note that in the intermediate core, due to previously collected samples around MFS, transgressive deposits were explored only partly.

Finally, five ${ }^{14} \mathrm{C}$ calibrated amino acid racemisation ages were estimated for bivalves, including specimens of upper shoreface Lentidium and offshore Corbula. These specimens were recovered from within the top most sample collected from a $\sim 25 \mathrm{~cm}$ thick, densely packed fossiliferous interval in the offshore distal sector (EM S4). These dates, along with others previously published (Scarponi et al., 2013; Campo et al., 2016, Fig. 1B), provide direct numerical insights into the geochronology and temporal resolution of the fossil record of the investigated region. Analyses were per formed at the Amino Acid Geochronology Laboratory Northern Arizona University (USA). All statistical analyses were performed using $\mathrm{R}$ ( $\mathrm{R}$ Development Core, 2016) and PAST (Hammer et al., 2001) softwares.

\section{Results}

The nMDS ordination of taphonomic variables indicates that nMDS axis 1 is positively correlated with taphonomic damage: low axis 1 values point toward high taphonomic alteration of samples (Fig. 2). Specifically, samples with high axis 1 scores are typified by the absence or scarcity of bioerosion, dissolution, ornamentation loss, and immuration. A high degree of bioerosion, color alteration, and complete ornamentation loss characterize samples with lower (negative) nMDS axis 1 scores.

Samples are regularly distributed along axis 1 of the ordination plot (Fig. 2). Samples from proximal (205 S6) and intermediate (205 S9) cores are located in the mid upper right quadrant of the nMDS plot and form adjacent, highly overlapping groups in the ordination space (Fig. 2). Samples retrieved from the distal (EM S4) core are more widely dispersed in the nMDS space, but show only limited overlap with the intermediate core samples and no overlap with the proximal core samples (Fig. 2). Plots of nMDS axis 1 sample scores along core depth show that taphonomic profiles are variable from site to site, the overall taphonomic damage, however, tends to increase from proximal to distal locations (Figs. 3-4). In both proximal and distal cores, the major peak in the taphonomic damage is recorded in the facies associations related to deeper settings (i.e., shoreface transition and offshore, respec tively), and in agreement with the maximum depth estimate (Fig. 3). In the intermediate core, peak damage occurs within the transgressive sand sheet-a meter scale lithosome with strong evidence of physical reworking. However, no samples at the level of estimated maximum water depth (Fig. 3) were available for taph onomic analyses. Minor peaks in nMDS axis 1 scores are also 
Table 1

Taphonomic variables and damage states used to score skeletal items from the Holocene Po Plain succession.

\begin{tabular}{|c|c|c|}
\hline \multicolumn{3}{|l|}{ Taphonomic primer } \\
\hline Variable & Evaluation of & State \\
\hline Ornamentation(orn.) & sculpture state of shell/fragment & $\begin{array}{ll}0 & \text { pristine or well preserved; } 1 \text { worn; } 2 \text { lost/completely erased } \\
3 & \text { smooth shell }\end{array}$ \\
\hline Immuration (imm.) & $\begin{array}{l}\text { precipitation of minerals on skeletons } \\
\text { (e.g., carbonates or gypsum) }\end{array}$ & 0 pristine; $1 \quad$ traces; 2 in part; 3 coated \\
\hline Fragmentation (frag.) & skeleton breakage & whole valve or specimen; 1 fragment, \\
\hline Color (col.) & colors and patterns on shell surface & $\begin{array}{ll}0 & \text { pristine/fresh; } 1 \text { faint/traces; } 2 \text { discolored/not visible; } \\
3 & \text { secondary color/pattern }\end{array}$ \\
\hline Dissolution (diss.) & dissolution on skeletal & not visible, 1 initial stage, 2 advanced stage \\
\hline Bioerosion (bioer.) & perforation or encrustation degree & not visible; 1 in part, 2 completely covered \\
\hline
\end{tabular}

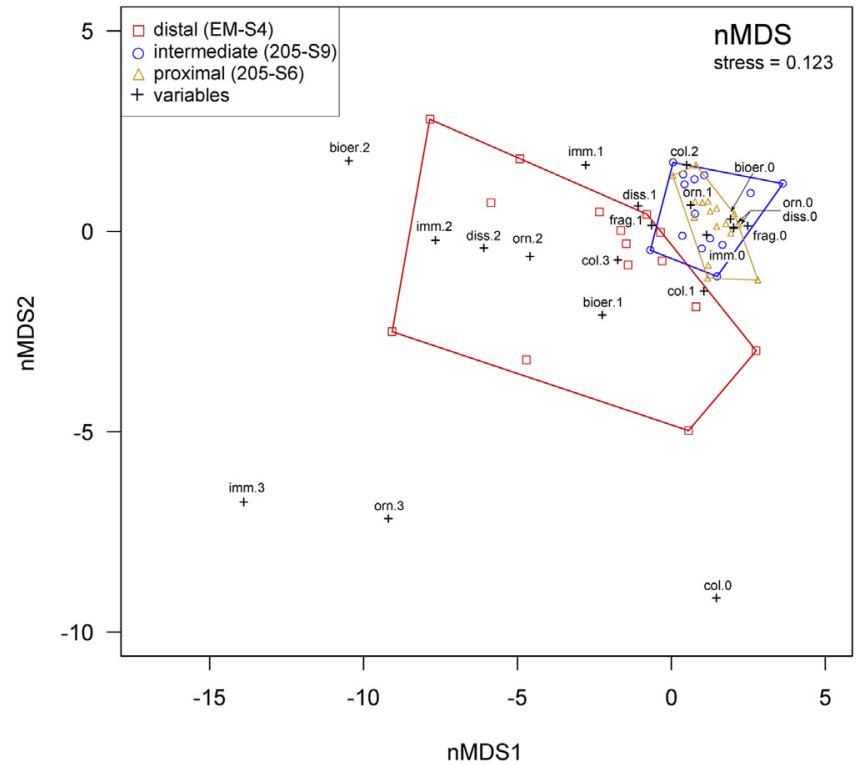

Fig. 2. nMDS in two dimensional space, based on Euclidean distance for z-standardized relative abundances of taphonomic variables of samples from the Holocene Po plain succession. Both taphonomic variables and samples are displayed.

observed at all three sites associated with facies shifts or across stratal boundaries (Fig. 3).

Finally, both bathymetric and taphonomic nMDS derived trends coupled with ecologic information of recovered species appear to be diagnostic of the transgressive facies associations.

Specifically, lagoon/bay deposits commonly show barren or sparse, macroskeletal remains of mainly brackish taxa (e.g., Cera stoderma glaucum, Abra segmentum; Fig. 4C, F and I). These deposits are characterized by an overall invariant and/or upward decreasing (well to fairly preserved) taphonomic degradation coupled with invariant to deepening upward bathymetric profiles (Fig. 3). ${ }^{14} \mathrm{C}$ calibrated shelly material from outer lagoon deposits from a com panion core yielded centennial time estimates of time averaging (see Scarponi et al., 2013 locality 4). Minor spikes in the taphonomic damage profile are mainly associated with lithofacies changes.

Transgressive sand sheet-TrSS intervals are characterized by fossiliferous, ecologically mixed assemblages of brackish to shallow marine taxa (e.g., Cerastoderma, and tellinids respectively; Fig. 4E and $\mathrm{H}$ ), with intermediate taphonomic degradation that increases basinwards (Fig. 3B-C). Previously ${ }^{14} \mathrm{C}$ calibrated amino acid racemisation (AAR) dates from the topmost of this fossiliferous sand sheet in the intermediate core yielded age offset of $\sim 3.9 \mathrm{ky}$ (Scarponi et al., 2013, Fig. 3B). Within this facies association the vertical changes in taphonomic damage follow a $v$ shaped pattern characterized by an increasing and then decreasing upward trend (Fig. 3B-C). These taphonomic changes developed within a bathymetrically invariant setting in the intermediate core (Fig. 3B). In the distal core, the bathymetric profile initially appears substantially invariant (i.e., observed changes are within the uncertainty of the estimate $\pm 1.8 \mathrm{~m}$ in Fig. 3), followed by shallowing. In contrast, fossiliferous and lithologically similar lower shoreface deposits that also developed across a bathymetrically invariant trend, can be easily distinguished from TrSS by their overall low shell damage, reversed taphonomic degradation trend (first decreasing and then increasing upward; Fig. 3A), and ecologically coherent (lower shoreface) monotaxic Chamelea gallina assemblages (Fig. 4B), framed within a centennial scale parasequence. This latter is nested within millennial scale parasequence 2 (no-radiometric data available; Fig. 1, Campo et al., 2016).

Offshore facies show variable taphonomic damage in relation to their position along the depositional profile (i.e., intermediate vs. distal). That is, offshore samples from the intermediate core show notably lower taphonomic degradation than offshore samples from the distal core (Figs. 3A, C and 4D, G). Only in the distal core we did observe a densely packed skeletal concentration ( $25 \mathrm{~cm}$ thick) of highly degraded (e.g., bioeroded and abraded) and ecologically non overlapping mollusks in association with maximum water depth (>20 m; Figs. 3C, 4G and 5). These assemblages are domi nated by species typical of Adriatic coralligenous assemblages that thrive in areas of minimal clastic sediment accumulation, low light and relatively low benthic energy levels (Ballesteros, 2006). The ${ }^{14} \mathrm{C}$ calibrated amino acid racemisation (AAR) ratios of the five shells did not include any outliers with aberrant amino acid sig natures (see screening procedure in Scarponi et al., 2013). The ages were consistent within each of the two analysed species. Specif ically, upper shoreface Lentidium valves yielded age estimates be tween 9.2 and $9.6 \mathrm{ky}$, whereas, ages of offshore Corbula specimens ranged between 0.9 and $1.2 \mathrm{ky}$ (see Table S1 in supplementary material). These layers of ecologically mixed and highly damaged faunal remains (Fig. 3C) suggest the presence of a fossiliferous condensed section-CS in the distal core (Figs. 4G and 5).

\section{Discussion and conclusion}

\subsection{Eco taphonomic patterns and their driving factors}

In back barrier settings, taphonomic patterns are relatively consistent along the investigated depositional onshore offshore profile. Scattered skeletal remains, characterized by low or decreasing upward taphonomic degradation, framed within a centennial scale residence time, suggest relatively high net accumulation rates. Preliminary estimates indicate average sedimentation rates of $2-6 \mathrm{~mm} / \mathrm{yr}$ in transgressive back barrier settings (Scarponi et al., 2013; Campo et al., 2016). 


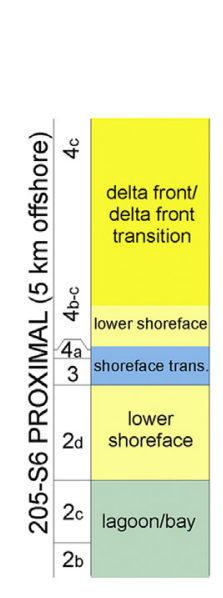

A)

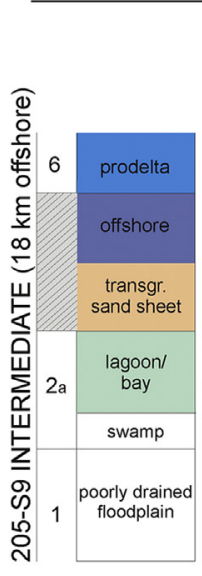

B)

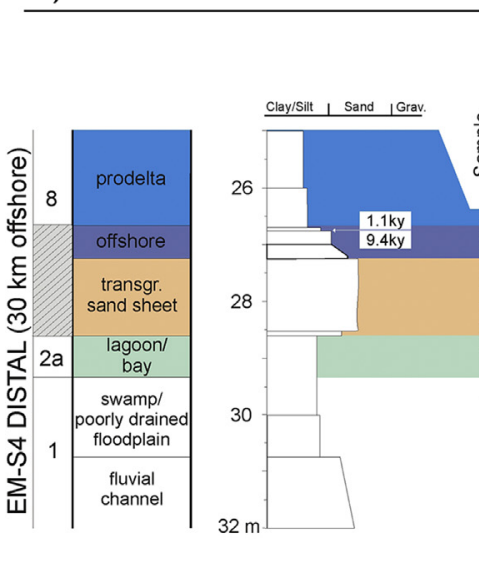

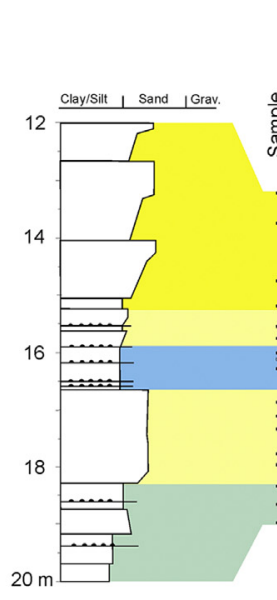

$-26$

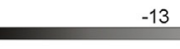

bathymetric profile
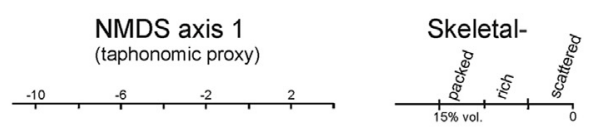

Sequence stratigraphy

taphonomic profile

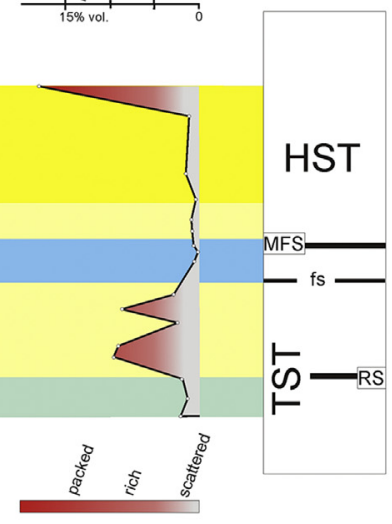

$\%$ vol. bioclasts

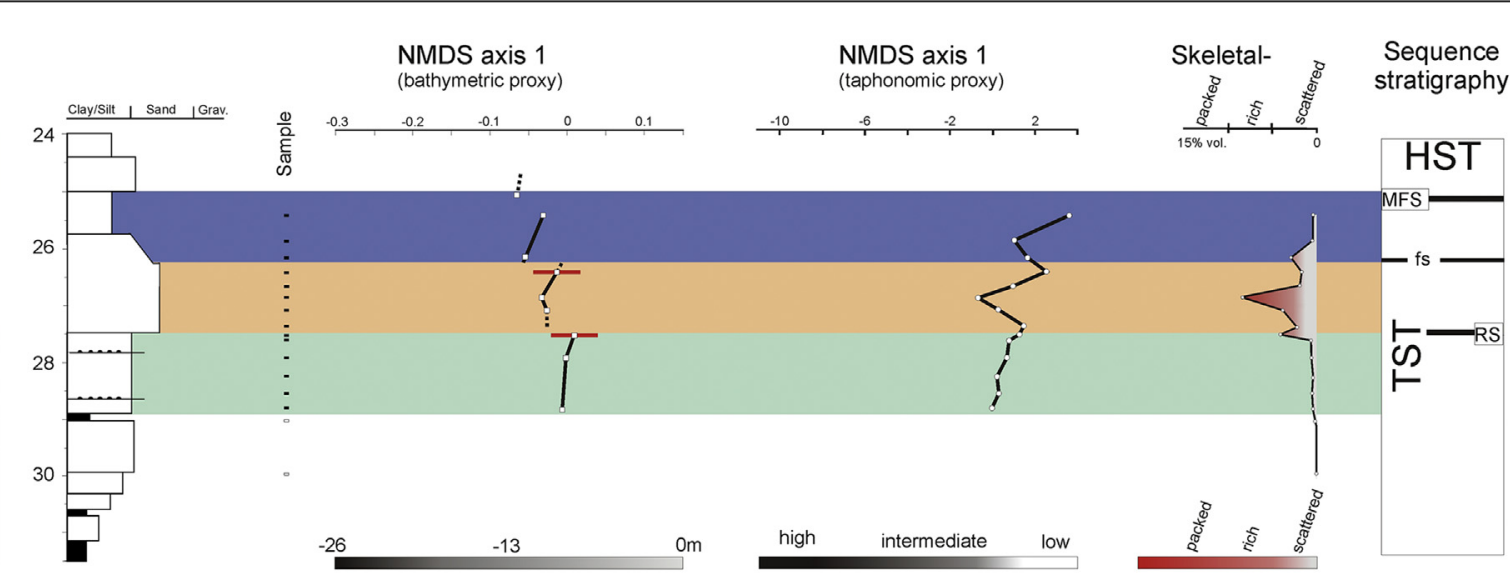

bathymetric profile

taphonomic profile

$\%$ vol. bioclasts

HST

C)

$\begin{array}{ll}\text { NMDS axis } 1 & \text { NMDS axis } 1 \\ \text { (bathymetric proxy) } & \text { (taphonomic proxy) }\end{array}$
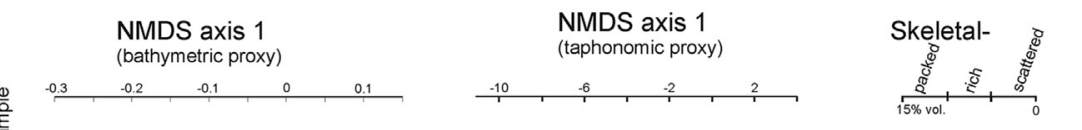

Sequence

stratigraphy

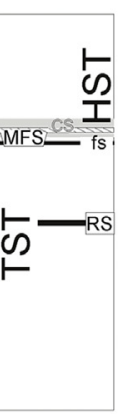

bathymetric profile

taphonomic profile

$\%$ vol. bioclasts

- barren sample - fossiliferous sample - +... sandy layer

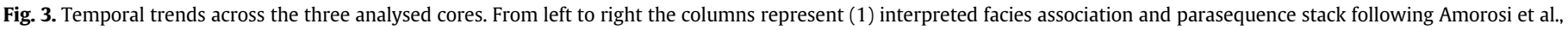

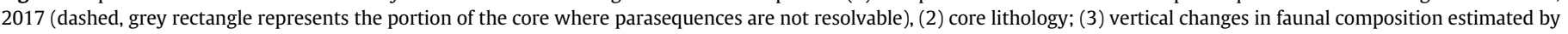

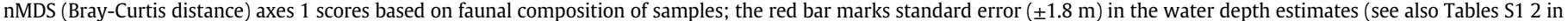

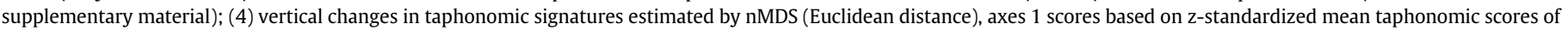

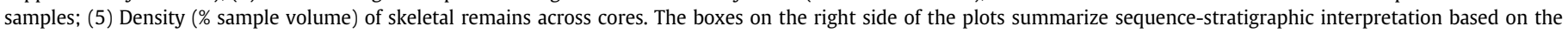

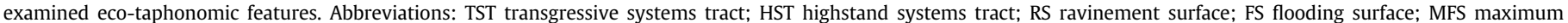

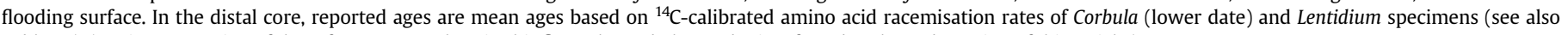
Table S3). (For interpretation of the references to colour in this figure legend, the reader is referred to the web version of this article.) 


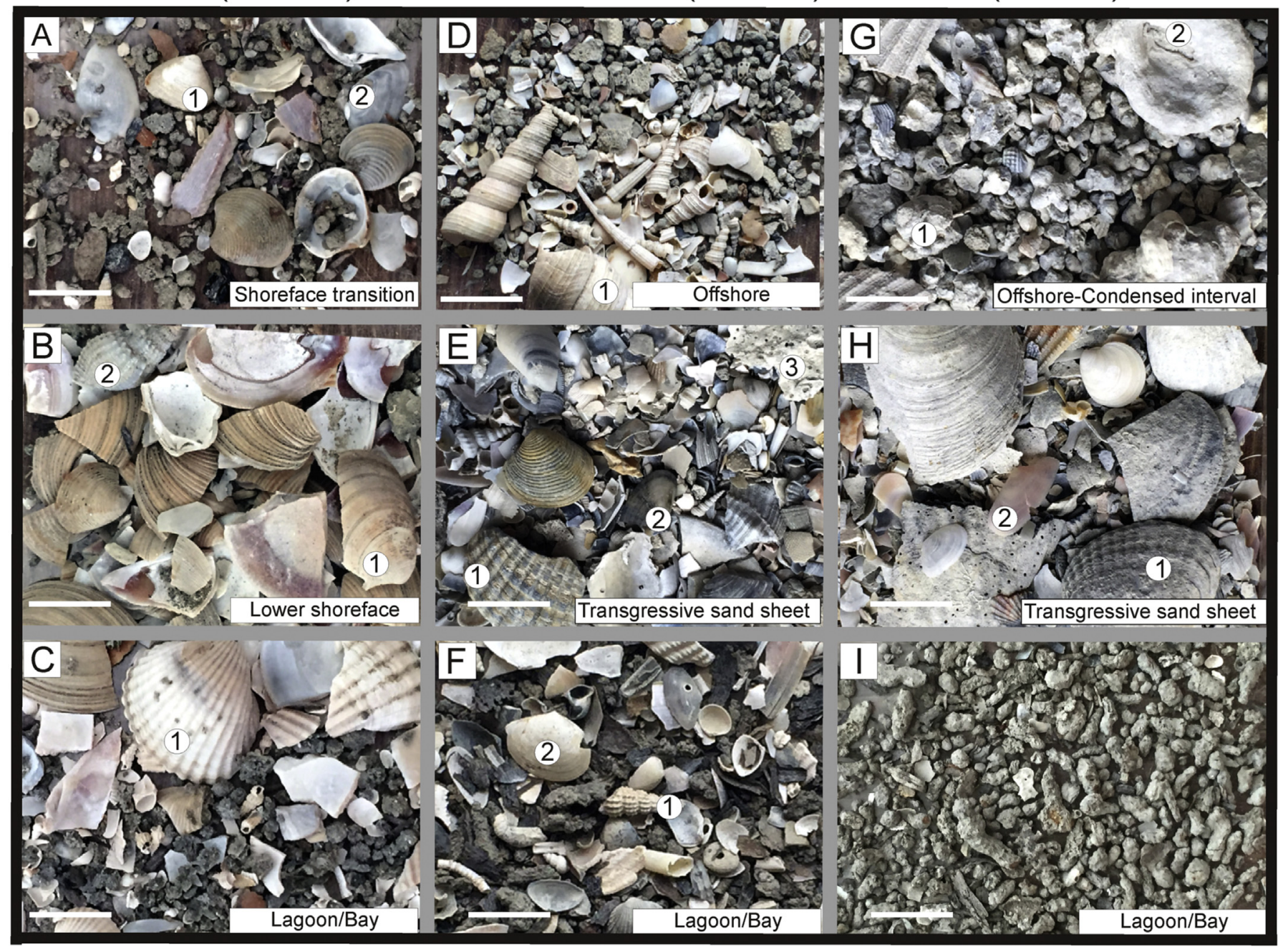

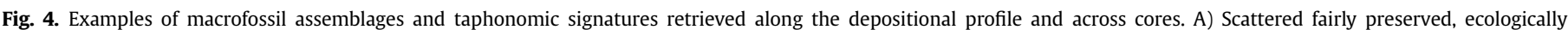

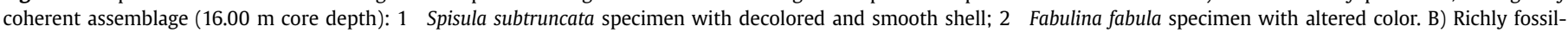

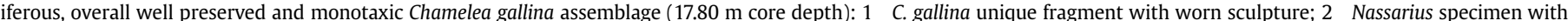

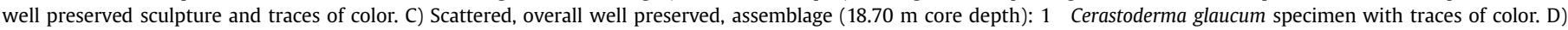

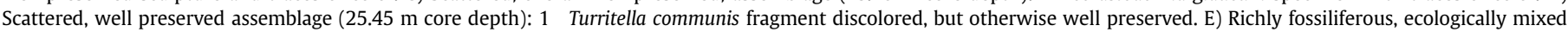

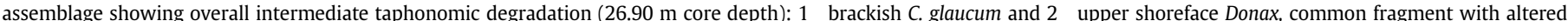

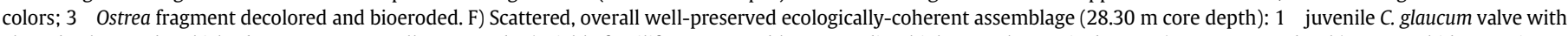

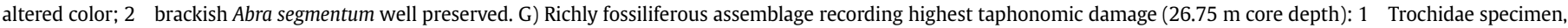

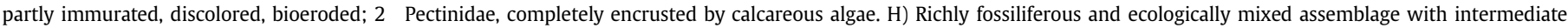

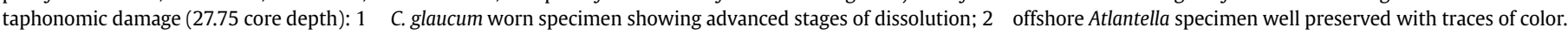

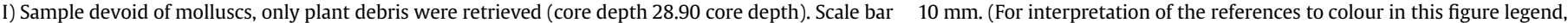
the reader is referred to the web version of this article.)

Within the marine TST, taphonomic patterns change predictably along the depositional profile and show increasingly higher time condensation, even for those samples that belong to the same facies association (i.e., TrSS and offshore) and show comparable faunal turnover and overlapping bathymetric profiles (e.g., the intermediate and distal portions; see Fig. 3). The basinward increase in taphonomic degradation coupled with increasingly poorer time resolution, suggests that changes in clastic supply, likely controlled by increasing distance from the shoreline and cyclonic oceanographic circulation patterns (Amorosi et al., 2016), were the major drivers in shaping the taphonomic signature of skeletal as semblages, especially in intermediate and distal cores (i.e., $>17 \mathrm{~km}$ offshore). These factors control the duration of sea floor exposure of skeletal remains (Figs. 1 and $3 \mathrm{~B}-\mathrm{C}$ ) and facilitate the development of taphonomic feedback (sensu Kidwell and Bosence, 1991, Fig. 4G) and intense degradation. Found in intermediate and distal cores, a meter thick transgressive sand sheet (TrSS; Figs. 3B-C and 5) represents ecologically mixed fossiliferous sed iments (Fig. 4E, H) and exhibits intermediate levels of fossil pres ervation. These characteristics of TrSS suggest that physical and biological reworking of skeletal rich and skeletal poor intervals outpaced net accumulation rates for a substantial period, estimated 3-4 ky (see chapter 4). However, fairly preserved associations characterizing top TrSS in both intermediate and distal cores (Fig. 3B-C), point to episodic progradation during an overall transgression (see also Cattaneo and Steel, 2003). In the distal core this interpretation is also supported by a slight shallowing upward tendency within uppermost TrSS and by a poorly fossiliferous thin 


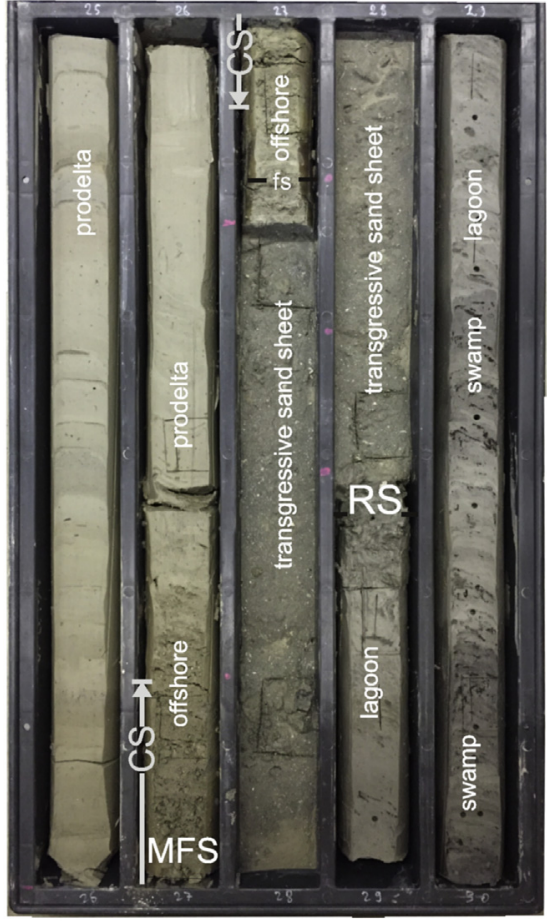

Fig. 5. Vertical stacking of facies associations in distal core EM-S4 (30 km offshore) with relevant sequence-stratigraphic units and surfaces as identified by taphonomic investigations. Core segments are $1 \mathrm{~m}$ in length. RS ravinement surface; CS con-densed section; MFS maximum flooding surface.

and laminated interval of silt/fine sand occasionally observed on top of the TrSS (see EM S4, 27.10-27.20 m in Figs. 3C and 5). Additionally in the distal sector, the presence of an ecologically condensed interval overlying the TrSS (Fig. 4G) suggests that low accumulation rates persisted even longer, although this core is located only $\sim 30 \mathrm{~km}$ offshore of its coeval shoreline (core EM S4). Here, rates of net accumulation are difficult to quantify, but are estimated to be $<<1 \mathrm{~mm} / \mathrm{yr}$ (see Campo et al., 2016).

The results reported here demonstrate that fossil condensation is clearly delineated within marine deposits of distal location, by highly degraded and polytaxic skeletal concentrations that mix together ecologically non overlapping species (Fig. 4G). This strong taphonomic signature recorded in this particular interval of core EM S4 developed in less than 10ky (according to radiometric derived ages, Fig. 1; Table S3). Conversely, facies associations and the bathymetric changes across core 205 S6 (Fig. 3A) indicate that backstepping deposits developed close to the shoreline $(<5 \mathrm{~km})$ throughout the entire marine transgressive phase. Here, clearly defined highly fossiliferous horizons are recorded. These horizons contain ecologically coherent faunal assemblages, framed within centennial scale parasequences, with the relatively lowest levels of taphonomic degradation (Figs. 1 and 4B). The unexpectedly low level of taphonomic alteration - given the relatively high energy setting (lower shoreface) in which those fossil horizons formed highlights the overriding importance of clastic sediment supply that lowers the residence time of shells within the taphonomically active zone, as well as high biological productivity in nearshore settings at the time of late transgression. An overall high rate of clastic sediment supply in such settings is also implied by the presence of scattered, fairly preserved fossil remains in the deepest proximal facies (shoreface transition at time of maximum transgression; Figs. 1 and 4A). Here, given ecologically coherent associations characterizing these nearshore deposits (see also section
5.2), the net sedimentation rates are inferred to be at least comparable with those recorded in back barrier settings throughout the entire transgressive phase. This outcome is consistent with the predictions of the R sedimentation model of Kidwell $(1985,1989)$. In the proximal portion of the gradient ( $<5 \mathrm{~km}$ offshore), however, variations in the production rate of biogenic skeletal remains (i.e., the $\mathrm{R}$ hardpart model; Tomasových et al., 2006) may have also played a role in forming fossiliferous assemblages.

\subsection{Eco taphonomic patterns and implications for paleobiology}

Back barrier settings are characterized by ecologically congruent fossil assemblages with low levels of taphonomic alter ation, which are indicative of relatively high net sedimentation rates in a low energy depositional environment. These ecological and taphonomic attributes indicate that back barrier facies repre sent a high quality and high resolution fossil record, consistent with submillennial time averaging of individual fossil horizons previously estimated via ${ }^{14} \mathrm{C}$ calibrated amino acid dating (Scarponi et al., 2013). Back barrier deposits are capped by a sligthly dia chronous ravinement surface [RS], which records marine flooding of older brackish depositional environments and is clearly sepa rated from the transgressive surface [TS] recognized on top of the Younger Dryas paleosol (Campo et al., 2016). The reworked taxa with, at most, intermediate taphonomic degradation associated with the RS indicate a reduced temporal resolution, which is consistent with the time averaging indicated by numerical dating of the RS shell lag (2 3ky in Scarponi et al., 2013). Lithosomes above the RS, capped by the MFS along dip, are suggestive of different patterns of sediment dispersal (see section 5.1).

These patterns indicate that the resolution and quality of the fossil record change predictably down dip. Specifically, the prox imal area is characterized by ecologically congruent, fairly preserved, monospecific fossil assemblages (Fig. 4B) due to sediment trapping at the time of maximum marine ingression. These as semblages have centennial scale resolution, as they occur within the centennial scale parasequence $2 \mathrm{~d}$ (Figs. 1B and 3A). In contrast, richly fossiliferous transgressive sand sheets (205 S9 and EM S4 cores), are characterised by ecological mixing and generally intermediate preservation that deteriorates down dip (Fig. 4E and $\mathrm{H}$ ). These characteristics indicate an overall decline in the quality and resolution of the fossil record offshore ( $18 \mathrm{~km}$ from shoreline). Quantitative estimates of time averaging in the topmost part of the trangressive sand sheet (TrSS) of 205 S9 core indicate substantial (multi millennial) temporal mixing ( $\sim \mathrm{ky}$ based on difference between means of dated Lentidium and Corbula shells; see horizon $6 \mathrm{~g}$ in Scarponi et al., 2013). In the distal core (EM S4), vertically stacked TrSS and a condensed section contain highly degraded skeletal assemblages (Figs. 3C and 5) affected by strong taphonomic feedbacks (Fig. 4G), implying greater deterioration of the fossil record for the distal sector. Preliminary $\mathrm{C}^{14}$ calibrated AAR dating on Corbula and Lentidium specimens retrieved from the top part of the CS indicates extensive time averaging spanning at least $8 \mathrm{ky}$ (Fig. 3C, Table S3). This estimate is also in good agreement with the radiometrically calibrated chronostratigraphic framework for this profile ( 7ky, Amorosi et al., 2017) and previ ously published radiometric data from a nearby core (Scardovari core in Correggiari et al., 2005 and references therein). In summary, transgressive lagoon/bay and nearshore facies are characterized by relatively high resolution and quality of the macrofossil record, whereas the more distal settings record stronger tapho nomic alteration and record higher levels of temporal mixing. In the offshore distal setting, eco taphonomic trends point to the development of strong taphonomic feedbacks and highest tapho nomic degradation (suggestive of both stratigraphic and fossil 
condensation). Amino acid racemisation dating indicates that such intense alteration can occur in a relatively short time span, less than $10 \mathrm{ky}$.

\subsection{Eco taphonomic patterns and implication for sequence stratigraphy}

The joint consideration of taphonomic, bathymetric, and fossil density trends across the study cores provides a record of distinctive signatures that are useful in characterizing facies associations and identifying surfaces and intervals of sequence stratigraphic significance.

Ravinement surface-RS. This ravinement surface, located a few meters above the TS, is associated with a sharp lithologic change within the TST (Figs. 3 and 5) across the study area. RS is commonly highlighted by a $\mathrm{cm}$ thick interval of ecologically mixed taxa that record a bathymetric shift toward deeper settings (Fig. 3). Along the depositional profile, the RS is characterized by variable fossil packing and non systematic fluctuations in taphonomic degradation. The lack of clear proximal distal trend could reflect the primary influence of local conditions, such as local scours or inherited topography, that may have influenced the taphonomic signature and fossil packing.

Maximum Flooding Surface-MFS. In the deepest water facies (shoreface transition) of the proximal core, a nMDS recorded deepening coupled with a peak in taphonomic damage suggest the position of the MFS at $\sim 16.00 \mathrm{~m}$ core depth (Fig. 3A). In contrast, the fossil density profile does not show any distinctive signature (Fig. $3 \mathrm{~A}$ ), and the MFS is associated with sparse, fairly preserved macroskeletal remains (Fig. 4A). Conversely, in the distal part, the MFS lies within a $\sim 15 \mathrm{~cm}$ thick, increasingly fossiliferous silty in terval with highly degraded remains in the lower part of the ecologically condensed section (26.90-27.05 $\mathrm{m}$ in Figs. 3C, 4G and $5)$. In the proximal and distal cores, the decreasing trend in bathymetric and taphonomic profiles associated with the low density of macrofaunal remains, marks the base of the highstand systems tract, which is represented by a thick, prograding delta front (proximal) to prodelta (intermediate seaward) succession (Figs. 3 and 5).

Minor transgressive flooding surfaces - In the proximal core, 205 S6, bathymetric and taphonomic profiles fail to indicate any flooding surface other than the RS and MFS. However, at $16.60 \mathrm{~m}$ core depth, the sharp contact between fine/medium grained sands and alternating silts and fine sand layers suggests a landward shift of facies (lower shoreface to shoreface transition) and points to a flooding event (Fig. 3A).

In the intermediate core, 205 S9, a significant bathymetric shift, coincident with a minor spike in fossil density (i.e., $26.15 \mathrm{~m}$ core depth Fig. 3B), suggests a flooding surface within the marine TST. However, only in the proximal portion of the depositional profile, the marine sedimentary package sandwiched between the RS and MFS can be subdivided into parasequences based on integrated ecotaphonomic and lithologic signatures. Conversely, in the distal and intermediate sectors, especially within the TrSS, the variability of investigated nMDS bathymetric estimates and a non systematic variation in taphonomy and fossil density, may reflect stochastic fluctuation in assembling of macrofaunal remains (Fig. 3). This makes it difficult to clearly identify individual flooding surfaces (only a shallowing upward trend characterizes the uppermost part of the TrSS).

\subsection{Closing remarks}

The integrated analyses of facies associations, taphonomic data, and their lateral changes along bathymetric profiles, made it possible to characterize spatio temporal trends in taphonomic degradation. These trends point to predictable changes in the quality and resolution of the fossil record, both spatially along the local depositional profile, and temporally through the transgressive systems tract: (1) transgressive nearshore deposits preserve a higher proportion of taphonomically pristine, internally simple and arguably less time averaged skeletal concentrations than their distal counterparts; (2) taphonomic degradation along the investigated profile is inversely related to net sediment accumulation rates and positively related to distance offshore. This indicates that the quality and resolution of the macrofossil record improves proximally along the depositional profile.

These inferences may be applicable not only to the studied area-a siliciclastic, semi enclosed, shallow basin influenced by a major river, but are likely transferrable to older successions accumulated within comparable depositional contexts. Finally, the quantitative approach applied here offers an independent strategy for testing sequence stratigraphic interpretations and augmenting core based sedimentary analyses with quantitative eco taphonomic proxies.

\section{Acknowledgements}

The authors thanks Ronal J. Steel and an anonymous reviewer for constructive criticisms that improved the quality of this research report. The study was supported by ExxonMobil Upstream Research Company and the NSF grant EAR 1559196: "Stratigraphic Paleobiology and Historical Ecology of Po Basin".

\section{Appendix A. Supplementary data}

Supplementary data related to this article can be found at http:// dx.doi.org/10.1016/j.marpetgeo.2017.03.031.

\section{References}

Abbott, S.T., Naish, T.R., Carter, R.M., Pillans, B.J., 2005. Sequence stratigraphy of the nukumaruan stratotype (Pliocene-Pleistocene, c. $2.081 .63 \mathrm{Ma}$ ), Wanganui Basin, New Zealand. J. R. Soc. N. Z. 35 (1 2), 123150.

Amorosi, A. Bruno, L. Campo, B., Morelli, A., Rossi, V., Scarponi, D., Hong, W. Bohacs, K.M., Drexler, T.M., 2017. Global sea-level control on local parasequence architecture from the Holocene record of the Po Plain, Italy. Mar. Pet. Geol. 113.

Amorosi, A., Colalongo, M.L., Pasini, G., Preti, D., 1999. Sedimentary response to Late Quaternary sea-level changes in the Romagna coastal plain (northern Italy).

Sedimentology 46 (1), 99121.

Amorosi, A., Rossi, V., Scarponi, D., Vaiani, S.C., Ghosh, A., 2014. Biosedimentary record of postglacial coastal dynamics: high-resolution sequence stratigraphy from the northern Tuscan coast (Italy). Boreas 43, 939954.

Amorosi, A., Maselli, V., Trincardi, F., 2016. Onshore to offshore anatomy of a late Quaternary source-to-sink system (Po Plain-Adriatic Sea, Italy). Earth-Sci. Rev.

153, 212237.

Aucoin, C.D., Brett, C.E., Dattilo, B.F., Thomka, J.R., 2016. Sequence-stratigraphic model for repeated "butter shale" Lagerstatten in the Ordovician (Katian) of the Cincinnati, Ohio region, USA. Can. J. Earth Sci. 53 (8), 763773.

Ávila, S.P., Ramalho, R.S., Habermann, J.M., Quartau, R., Kroh, A., Berning, B., Johnson, M., Kirby, M.X., Zanon, V., Titschack, J., Goss, A., da Silva, C.M. Cachao, M., Madeira, J., 2015. Palaeoecology, taphonomy, and preservation of a lower Pliocene shell bed (coquina) from a volcanic oceanic island (Santa Maria Island, Azores). Palaeogeogr. Palaeoclimatol. Palaeoecol. 430, 5773. https://www.scopus.com/sourceid/13985?origin recordpage.

Ballesteros, E., 2006. Mediterranean Coralligenous assemblages: a synthesis of present knowledge. Oceanogr. Mar. Biodivers. Annu. Rev. 44, 125195.

Brady, M., 2016. Middle to upper Devonian skeletal concentrations from carbonatedominated settings of North America: investigating the effects of bioclastic input and burial rates across multiple temporal and spatial scales. Palaios 31 (6) 302318.

Brett, C.E., 1998. Sequence stratigraphy, paleoecology, and evolution; biotic clues and responses to sea-level fluctuations. Palaios 13 (3), 241262.

Bruno, L., Amorosi, A., Severi, P., Costagli, B., 2016. Late Quaternary Aggradation Rates and Stratigraphic Architecture of the Southern Po Plain, Italy. Basin Research. http://dx.doi.org/10.1111/bre.12174.

Calabrese, L., Perini, L., Lorito, S., Luciani, P., Martini, A., Severi, P., Correggiari, A. Remia, A., 2016. 3D modelling of the Holocene succession in the southern Po Delta (Italy): from geology to applications. Ger. J. Geol. 167 (4), 339352. 
Campo, B., Vaiani, S.C., Amorosi, A., 2016. Sequence stratigraphy and late Quaternary paleoenvironmental evolution of the Northern Adriatic coastal plain (Italy). Palaeogeogr. Palaeoclimatol. Palaeoecol. 466, 265278.

Cantalamessa, G., Di Celma, C., Ragaini, L., 2005. Sequence stratigraphy of the Punta Ballena Member of the Jama Formation (Early Pleistocene, Ecuador): insights from integrated sedimentologic, taphonomic and paleoecologic analysis of molluscan shell concentrations. Palaeogeogr. Palaeoclimatol. Palaeoecol. 216 (1), 125.

Cattaneo, A., Steel, R.J., 2003. Transgressive deposits: a review of their variability. Earth Sci. Rev. 62, 187228

Correggiari, A., Cattaneo, A., Trincardi, F., 2005. Depositional patterns in the LateHolocene Po delta system. In: Bhattacharya, J.P., Giosan, L. (Eds.), Concepts, Models and Examples, vol. 83. SEPM, Special Publication, pp. 365392

Danise, S., Holland, S., 2017. Faunal response to sea-level and climate change in a short-lived seaway: jurassic of the Western Interior, USA. Palaeontology 60, 213232.

Dominici, S., 2001. Taphonomy and paleoecology of shallow marine macrofossil assemblages in a collisional setting (late Pliocene early Pleistocene, western Emilia, Italy). Palaios 16 (4), 336353.

Giannetti, A., Monaco, P., 2015. Definition of sequence through ichnocoenoses and taphofacies: an example from the Sàcaras Formation (early Cretaceous, eastern Spain). Palaeogeogr. Palaeoclimatol. Palaeoecol. 438, 7080.

Hammer, Ø., Harper, D.A.T., Ryan, P.D., 2001. PAST: paleontological statistics software package for education and data analysis. Palaeontol. Electron. 4 (1), 9. Holland, S.M., 2000. The quality of the fossil record: a sequence-stratigraphic perspective. Paleobiology 26, 148168.

Horodyski, R.S., Holz, M., Grahn, Y., Bossetti, E.P., 2014. Remarks on sequence stratigraphy and taphonomy of the malvinokaffric shelly fauna during the KACAK event in the apucarama sub-basin (paraná Basin) Brazil. Int. J. Earth Sci. 103 367380

Huntley, J.W., Scarponi, D., 2012. Evolutionary and ecological implications of trematode parasitism of modern and fossil northern Adriatic bivalvs. Paleobiology 38, 4051.

Kidwell, S.M., 1985. Palaeobiological and sedimentological implications of fossil concentrations. Nature 318 (6045), 457460

Kidwell, S.M., 1986. Models for fossil concentrations: paleobiologic implications. Paleobiology 12 (1), 624

Kidwell, S.M., 1989. Stratigraphic condensation of marine transgressive records: origin of major shell deposits in the Miocene of Maryland. J. Geol. 1 24. Kidwell, S.M., Bosence, D.W., 1991. Taphonomy and Time-averaging of Marine Shelly Faunas. Taphonomy: Releasing the Data Locked in the Fossil Record. Plenum, New York, pp. 115209

Meldahl, K.H., 1990. Sampling, species abundance, and the stratigraphic signature, of mass extinction: a test using Holocene tidal flat molluscs. Geology 18 (9), 890 893.
Patzkowsky, M.E., Holland, S.M., 2012. Stratigraphic Paleobiology: Understanding the Distribution of Fossil Taxa in Time and Space. University of Chicago Press. R Core Team, 2016. R: a Language and Environment for Statistical Computing. R Foundation for Statistical Computing, Vienna, Austria. https://www.R-project. org/.

Scarelli, F.M. Barboza, E.G., Cantelli, L., Gabbianelli, G., 2017. Surface and subsurface data integration and geological modelling from the Little Ice Age to the present, in the Ravenna coastal plain, northwest Adriatic Sea (Emilia-Romagna, Italy). Catena 151,115

Scarponi, D., Angeletti, L., 2008. Integration of palaeontological patterns in the sequence stratigraphy paradigm:A case study from Holocene deposits of the Po Plain (Italy). Geo Acta 7, 113.

Scarponi, D., Kowalewski, M., 2004. Stratigraphic paleoecology: bathymetric signatures and sequence overprint of mollusk associations from upper Quaternary sequences of the Po Plain, Italy. Geology 32 (11), 989992.

Scarponi, D., Kowalewski, M. 2007. Sequence-stratigraphic anatomy of diversity patterns: late Quaternary benthic mollusks of the Po Plain, Italy. Palaios 22 (3), 296305.

Scarponi, D., Kaufman, D., Amorosi, A., Kowalewski, M., 2013. Sequence stratigraphy and the resolution of the fossil record. Geology 41 (2), 239242.

Scarponi, D., Huntley, J.W., Capraro, L., Raffi, S., 2014. Stratigraphic paleoecology of the Valle di Manche section (Crotone Basin, Italy): a candidate GSSP of the

middle pleistocene. Palaeogeogr. Palaeoclimatol. Palaeoecol. 402, 30 43. Scarponi, D., Della Bella, G., Dell'Angelo, B., Huntley, J.W., Sosso, M., 2016. Middle Miocene conoidean gastropods from western Ukraine (Paratethys): integrative taxonomy, palaeoclimatological and palaeobiogeographical implications. Acta Paleontol. Pol. 61, 327344

Stefani, M., Vincenzi, S., 2005. The interplay of eustasy, climate and human activity in the late Quaternary depositional evolution and sedimentary architecture of the Po Delta system. Mar. Geol. 222 223, 1948.

Storms, J.E.A., Weltje, G.J., Terra, G.J., Cattaneo, A., Trincardi, F., 2008. Coastal dynamics under conditions of rapid sea-level rise: late Pleistocene to Early Holocene evolution of barrier-lagoon systems on the northern Adriatic shelf (Italy). Quat. Sci. Rev. 27 (11), 11071123.

Tomašových, A., Fürsich, F.T., Olszewski, T.D., 2006. Modeling shelliness and alteration in shell beds: variation in hardpart input and burial rates leads to opposing predictions. Paleobiology 32 (2), 278298.

Wittmer, J.M., Dexter, T.A., Scarponi, D., Amorosi, A., Kowalewski, M., 2014

Quatitative bathymetric models for late Quaternary transgressive-regressive cycles of the Po Plain, Italy. J. Geol. 122 (6), 649670.

Zecchin, M., Caffau, M., 2011. Key features of mixed carbonate-siliciclastic shallowmarine systems: the case of the Capo Colonna terrace (southern Italy). Ital. J. Geosci. 130 (3), 370379

Zecchin, M., Catuneanu, O., 2013. High-resolution sequence stratigraphy of clastic shelves I: units and bounding surfaces. Mar. Pet. Geol. 39 (3), 125. 